\title{
VET Realignment and the Development of Technical Elites: Learning at Work in England
}

\author{
Bill Esmond* and Liz Atkins \\ University of Derby, Institute of Education, Kedleston Road, Derby, \\ UK, DE22 $1 G B$
}

Received: 31.10.2019, Accepted: 11.05.2020, Published: 11.08.2020

\begin{abstract}
Context: An enhanced role for work-based learning is advocated increasingly widely across industrialised countries and by international Vocational Education and Training (VET) policies. However, this is framed differently in each country by long-term policy orientations that reflect VET's relationship with wider economic and social formations. These national differences reflect path dependency but also distinctive responses to contemporary challenges such as globalisation. In England, recent reforms strengthening workplace learning are constrained by existing patterns of skill formation and may be shaped by further market liberalisation and divergence from social and economic policies in Europe.
\end{abstract}

Approach: The study examined the relationship between greater emphasis on workplace learning in England and societal change, addressing the research question: how are early experiences of work in England, as part of young people's full-time education programmes, positioning them for future employment? Case studies were organised around apparently distinctive placement types that had emerged from earlier studies. Using the constant comparative method, the team identified a series of categories to distinguish the way each type of work-based learning positioned students in a particular type of labour market transition.

Findings: Evidence emerged of divergence in England's "further education" system, across mainly male "technical" routes, young people on vocational courses preparing them for

*Corresponding author: w.esmond@derby.ac.uk 
routine, low-skilled, precarious employment, and an area of greater uncertainty preparing young people for digital routes linked to the "new economy". Key dimensions of difference included study locations, discourses of occupational status, types of valued learning content, approaches to socialisation, sources of expertise and processes of credentialisation. In each case, learning at work served to position students for a particular type of labour market transition, which we characterise as technical elite formation, welfare VET and new economy precarity.

Conclusion: Approaches to workplace learning in England already reflect social distinctions but entail the possibility of reinforcing these, supporting a more hierarchical pattern of labour market transition. Whilst the upper strata of VET shift their purpose to support the formation of new "technical elites", others face the possibility of further marginalisation. Such new inequalities could become central to a further fragmented society in a post-Brexit, post-COVID-19 Britain. Other European states facing challenges of globalisation and the transition to services are also likely to experience pressures for VET stratification, although they may seek less divisive solutions.

Keywords: Policy Analysis, Education and Training Reform, Workplace Education and Training, Social Justice, Vocational Education and Training, VET

\section{Introduction}

Patterns of transition to employment and adulthood are shifting across Europe, as countries and regions seek to increase the role of early experiences of work in professional, technical and vocational programmes of study. Interest in such activity now extends from Vocational Education and Training (VET) at tertiary level, with half of all EU jobs expected to require higher qualifications, to the recognition of informal learning (Kis \& Windisch, 2018; European Commission, 2016). Learning in the workplace has long been associated with favourable transitions into productive, stable and rewarding employment, as well as social inclusion for disadvantaged groups, with the workplace seen as offering opportunities to develop conceptual and "soft" skills alongside technical expertise (Nilsson, 2010; Employment and Social Developments in Europe, 2015). International bodies, including the OECD and European Union, support these developments with discourses of human capital and national competitiveness (European Commission, 2016; Mühlemann, 2016). Yet the generalised approaches that characterise such international agendas are problematised by the significant differences in the role that workplace learning plays in national education and skills systems across Europe (Méhaut \& Winch, 2012; Bosch, 2017).

The means by which learning at work is integrated into VET systems constitutes one of the chief distinctions among national systems. Iannelli and Raffe (2007) depicted a contrast 
between countries they described as having employment-based transition systems, enjoying lower youth unemployment and social inequality, and countries with "education-based" systems that focused on transitions from school to higher education. Greinert's (2005) noted distinction between three models of VET compared the German dual training system, combining learning in industry and school settings, school-based vocational education in France and the market-based post-school training of England. Political economists have noted the wider significance of vocational education for economic and social policy, contrasting "collectivist" approaches in Germany and its neighbours to "liberal market" systems in AngloSaxon countries, basing their analysis on the relationship between VET and related fields such as welfare and banking (Busemeyer \& Trampusch, 2012; Sorge \& Streeck, 2018). These generalised comparative models inevitably simplify differences across and within national and even regional boundaries but provide useful starting points for analysis of different systems. These models also reflect path-dependency: Greinert (2005) described the emergence of major models from the circumstances of industrialisation in each country. Thelen (2004) provided a detailed historical analysis of the way contestation among social actors produced the settlements underpinning contemporary skills systems in each country. Such historical pathways have entailed the creation of powerful frameworks to support workplace learning, such as the Handelskammer in Germany, whilst depriving countries such as France of embedded structures that support apprenticeship (Gehin, 2007).

However, our chief concern in this paper is not simply the practicality of implementing policies to enhance the role of workplace learning but the distinctive societal impacts of such policies. In Germany and some neighbouring countries, dual training has long been seen as supporting greater social equality, initially by supporting a "diversified quality production" (Streeck, 1991) that sustained a larger manufacturing base, staffed by highly-skilled workers; and more recently extending VET into the service sector, facilitating the continuation of relatively low wage inequality (Sorge \& Streeck, 2018). It is less clear that countries where VET was earlier confined to state-run school education, such as France, Holland, Sweden and Norway, have achieved the same results through an increased role for firm-based training (Hardy \& Ménard, 2009; Michelsen \& Stenström, 2018; Wesselink et al., 2010). Countries with long-established dual training systems continue to record significantly lower rates of unemployment for 15-24-year olds in 2018 (Germany 6.2\%, Austria 9.4\%, Denmark 10.5\%) than those for countries where the state has played a stronger role (France 20.7\%, Sweden $16.8 \%$ ), although this compares to more pronounced differences a decade earlier (Eurostat, 2019). Yet employment is not the only measure of equality, and in the UK, where skills formation and deployment are determined largely through market mechanisms, liberal market policies have contributed to a more unequal society, with stratified education systems (devolved to the four countries making up the UK) variously implicated in these processes. Higher 
rates of participation in higher education, reaching $50 \%$ of the age cohort in 2019 , powerfully influence the shape of secondary education with a strong academic/vocational divide.

This paper examines how an increasing emphasis on workplace learning in England, the country in Europe most strongly representative of the liberal market model, is reshaping the transitions that young people make to employment (and, by implication, to adulthood). England has a larger higher education system than others in Europe, accompanied by the stratification common to "high-participation" systems (Marginson, 2016) and skills training largely takes place separately from general education. Its main contributions to European VET policy, such as qualification frameworks built around competency-based outcomes, have since been contested internationally (Clarke \& Winch, 2015; Ante, 2016). Learning at work has become an increasingly important element of full-time vocational education, following the Wolf Review (Wolf, 2011) and the development of "technical education" or "T Levels" (Department for Education/Department for Business, Energy, Innovation and Skills [DfE/ DBEIS], 2016). However, learning at work can offer different opportunities to individuals and occupational groups, according to their positions in work hierarchies and processes (Illeris, 2011; Felstead et al., 2009). This raises questions about how learning at work may affect the contribution made by VET to income equality and social justice, in relation to different national settings.

This paper therefore reports a study of the relationship between greater emphasis on workplace learning in England and societal change, addressing the research question: how are early experiences of work in England, as part of young people's full-time education programmes, positioning them for future employment roles? In the study we sought to uncover the way that changes in the economy and in society are both reflected and reinforced by policy in this area. The nature of recent educational policy change in England is discussed in the following section, along with examination of its socio-economic background. This is followed by a discussion of the methods used in the study and an exposition of the findings. Finally, the paper concludes with discussion of their significance for the future shape of further education and skills in England, and the possibility that these changes may have wider significance for VET elsewhere in Europe.

\section{Workplace Learning in England}

The introduction having provided a framework setting out the major distinctions among European countries, this section examines developments in England pertinent to the study: The recent move towards workplace learning and its socio-economic context. This section summarises the recent introduction of "industry placements"; analyses the specific changes in economy and society that provide their context; explains how the patterned responses of policymakers and key institutions have shaped the implementation of policy; and examines 
in detail how this has played out in the development of skills policy for England. A drive to increase the contribution of workplace learning to England's mainly vocational "further education" (FE) system has been strengthened since Conservative-led governments came to power in 2010. A planned increase in apprenticeship numbers has been followed by the replacement of "frameworks" or packages of qualifications with "standards" designed by employer-led "trailblazer groups" (Richard, 2012; UK Government, 2015). Short periods of work-based learning also became mandatory for full-time advanced secondary vocational programmes following the Wolf Report (Wolf, 2011). More ambitiously, the Sainsbury Review (Independent Panel on Technical Education, 2016) proposed to supersede a vocational system of "13,000 qualifications, many of them of little value" (Independent Panel for Technical Education, 2016, p. 6) with fifteen routes of "technical education", mainly distinguished by the addition of work placements between 1 and 3 months in length. Promoted with reference to the need to learn "lessons of the past or from abroad" (Boles, 2016, p. 5), it called for curricula developed by "industry experts" and a "transition year" for those unable to access the system. However, these practices have been inaugurated through the distinctive, marketbased approaches that UK governments have used to shape further education and the skills system in England, presented in the consumerist terms of giving "every young person ... two choices: The academic or the technical option" (DfE/DBEIS, 2016, p. 7).

The economic challenges facing the UK economy are not qualitatively different from those facing other countries, although the shift to services has moved further than elsewhere in northern Europe: In 2017 83\% of the UK workforce was engaged in service work, rising from 64\% in 1978 (Office for National Statistics [ONS], 2018). This has included a growth in internationally traded services requiring highly skilled workers, but also in sheltered but lowvalue personal services which offer substantially lower rewards and are characterised by precarious employment (Wren, 2013). Many manufacturing jobs for which further education colleges (the country's main VET institutions) primarily trained young people in the past have disappeared in response to technological change. These developments have contributed to the polarisation of labour markets, with a concentration in both high-skilled and lowskilled employment, described as an "hourglass economy" (Goos \& Manning, 2007). These economic developments have been linked to social realignment, calling for new theorisation of young people's transitions (Avis \& Atkins, 2017). Nevertheless, UK government policies have sought in particular to address needs for skilled workers and those in the "new economy" who are deemed to have been poorly served by FE in England.

Such mid-level occupations remain valued labour market opportunities yet are also subject to skills shortages. Whilst much reduced in number, they have not seen significant falls in wages, implying productivity gains (Acemoglu \& Autor, 2011; McIntosh, 2013). Holmes and Mayhew (2012) drew attention to the position of those earning mid-level wages whilst in apparently high-status jobs, which Wren (2013) suggested implied that workers in these 
roles have taken on additional responsibility. These are not secure professionals; nor elites in the traditional sense of small, powerful, professional groups at the top of society, struggling to capture and control "the jurisdictional work domains and labour market shelters through which professionalization projects are collectively mobilized" (Reed, 2018, p. 298). However, those entering these roles will occupy a relatively privileged position compared to those employed in routine, part-time and insecure jobs, in between periods of joblessness.

By contrast, many young people entering FE in England exhibit characteristics of significant social and educational exclusion, lacking access to valorised capitals: most also have negative previous educational experience and a history of low attainment. Conceptualised in policy as having low aspirations (despite research evidence to the contrary) they are problematised as being "disaffected" and "disengaged" (e.g. Atkins, 2009, 2017; Billett et al., 2010). These already have few options but to engage with a limited range of low-level vocational programmes, argued to offer an impoverished curriculum which is only weakly work-related, and to have minimal exchange value in the labour market (Wolf, 2011; Keep \& James, 2012). A similar prospect faces those young people - mainly women - preparing for occupation in service industries such as care, hairdressing, and beauty therapy. The "new economy" of digital and creative occupations that attracts many young people into vocational pathways shares several of these features in fragmented industry structures. The rise in the so-called "gig economy" with associated zero-hours contracts, and other "forms of contingent work" such as self-employment (Thompson, 2019, p. 19-20) has led to a marked increase in job insecurity, in-work poverty "churn" between insecure work, benefits claimancy, and government training schemes, well documented over an extended period (MacDonald \& Marsh, 2005; Simmons \& Thompson, 2011; Shildrick et al., 2012).

The low-pay, low-skill, routinised occupations which low-attaining young people might previously have accessed are now in decline across Europe as a whole, limiting the opportunities available to this group of young people (European Centre for the Development of Vocational Training [Cedefop], 2018; Keep \& James, 2012; Billett et al., 2010). The changing nature of the labour market, and that an individual's relative chance of finding employment is heavily mediated not only by the availability of work, but by social class, gender and ethnic group membership, is seldom acknowledged in policy discourses (Simmons, 2009, p. 143; Simmons \& Thompson, 2011, p. 29). There is an absence of consideration of those transitions which are variously extended, fractured, difficult, troubled and/or precarious (Atkins, 2017). For these learners, earlier policy initiatives focussed on creating "ladder-like" (Hodkinson et al., 1996) progression into the labour market and some service occupations, notably in care roles, are already mediated by work placement, so that the implementation of T Levels builds on existing patterns of "work experience". These issues are further complicated for students on courses associated with the "new economy" where "the workplace" can take very different forms. 
These developments do not entirely determine that education and labour market poli-cies will support and strengthen this growing social divide. However, increased emphasis on employer prerogative makes this more likely. Arrangements bringing together UK government, employer and trade union representatives lie far in the past. Following the Industry Training Act (Ministry of Labour, 1964), training boards once made recommendations for training and further education, levying employers and paying out training grants: In 196970, 26 boards raised $£ 175$ million from a million employers (Cantor \& Roberts, 1972, p. 86). But from the 1980s, liberalisation and market measures have dominated skills development in Britain. Conservative governments closed 16 training boards and the tripartite Manpower Service Commission (Ainley \& Corney, 1990); government schemes for the young unemployed funded third-party firms to provide training and brokerage (Chankseliani \& Relly, 2015); FE colleges came to provide more full-time courses, delaying labour market entry and providing progression to universities, becoming subject to intense performativity under both Conservative and New Labour governments (Hodgson et al., 2017). Compared to the role of those European governments that provide legal support for collective arrangements among education providers and labour market partners, the role of government in English skills formation is limited to create favourable market conditions for competing education providers to meet employer needs.

Consequently, the Sainsbury Review is also to be implemented through a voluntarist (for employers) framework: This places the task of organising learning opportunities in the lap of provider organisations, mainly FE colleges. In early pilots of work placements, these were most successful where labour market demand was strong and employers were able to select students who might be valued future employees; colleges found it harder to place students in attractive placements for low-level service roles (Newton et al., 2018). The "T Level" qualifications have been introduced more slowly and partially than first envisaged and, rather than replacing other vocational qualifications, are increasingly seen as a route into "higher technical education", for those destined for skilled occupations.

The apparent widening of the gap among these groups raises important questions about how the shift of learning into the workplace is beginning to play out within the framework of English education, with the possibility of ameliorating or exacerbating old and emerging inequalities. The study described here therefore focused specifically on students undertaking early work experiences as part of their studies, in order to answer the question of how this positions them for future employment. The methodology of the study is discussed in the following section. 


\section{Research Design and Methods}

The development of workplace learning as part of upper secondary education remains at an early stage in England, with substantial placements (a minimum of 45 days per academic year) forming part of the first phase of T Levels from 2020. However the study was able to address the research question of how these experiences are differentiated through an empirical study that drew on both existing placement experiences and their development. In this section we address the selection of case studies, data collection and its ethics, and the method of analysis.

\subsection{Case Study Selection}

Case studies were developed, using a multiple case study design which anticipated different patterns of theoretical replication (Yin, 2018). Earlier studies of work-based learning and placement development work (Esmond, 2018; Newton et al., 2018) had suggested areas of divergence in placement practice, and these were expected to provide useful data about how such practices shaped students' transitions to different types of employment: Initially four cases were planned. However, as Yin (2018) points out, case definition is an iterative process, in which the tentative definition is derived from the research questions but can be revisited during the study (2018, p. 29-30). The data began to cluster around three types of provision, leading to three case studies in three clusters of further education colleges. These had the added benefit of each including one of the three "T Level" subjects. The first provided professional construction courses (a T Level subject) sharing an emphasis on technical knowledge with some manufacturing provision, which we characterise as a "professional-technical" case. The second, "care and personal services" case collected data from in personal services and early years education (a second T Level) provision: These share an emphasis on practice with other vocational courses which, no matter whatever their intrinsic or social value, tend to lead to employment with relatively low social status. The third, in digital and creative fields, prepared young people for roles in the so-called "new economy": The third initial T Level is offered in software engineering. We invited participation from colleges which had departments with nationally-recognised expertise in these areas. Teachers and students from the identified departments were invited to participate and did so on a self-selection basis. All students had enrolled on nationally certificated level 3 programmes in one of the specified areas.

\subsection{Data Collection and Ethics}

The collection of data sought as much as possible to capture students' experience of employment, and data gathered included the study of policies and documents through which 
these placements had been organised and students had reflected on their experience. A more important focus, however, was collection of data through semi-structured qualitative interviews which utilised film elicitation (Nichols, 1991; Harper, 2002). Showing discussion of workplace learning among college tutors, work-based educators and employers, film elicitation (an adaptation of photo elicitation, see Atkins \& Duckworth, 2019; Rose, 2016) was specifically used to surface issues in placement learning. Participants included students who had experienced work-based learning, and their teachers; interviews explored their experiences and perspectives on learning in the workplace, and how participants expected placements might support their progression into secure and responsible job roles.

Ethical approval was sought from, and granted by, the University where members of the research team worked. The design and conduct of the project were consistent with the British Educational Research Association (BERA) ethical guidelines (2018).

\subsection{Data Analysis}

Interview data were subject to thematic analysis utilising the constant comparative method (Corbin \& Strauss, 2015). The constant comparative approach has its origins in grounded theory, with Glaser (1965) distinguishing this from the use of prior fixed codes:

the analysis cannot usefully be confined to the practice of coding first and then analyzing the data, since the analyst, in direct pursuit of his purpose, is constantly redesigning and reintegrating his theoretical notions as he reviews his material. (p. 437)

As Wellington (2015) recommends for case studies, this inductive and iterative process began with each team member's "immersion, swimming around in and poring over the case[s]" (p. 173) in advance of the development of codes. Next, the process of team-based review refined the scope of the cases and began to develop the categories which defined their key differences, leading to a shared and robust interpretation of the data. This stage aims to "discern conceptual similarities, to refine the discriminative power of categories, and to discover patterns" (Tesch, 1990, p. 96). Finally, the team was able to produce definitional statements for each case across a series of categories that distinguished the way each type of work-based learning positioned students in a particular type of labour market transition. These are set out as a series of related categories in the following results section, which ends with three ideal types of social formation that the team identified to characterise students' labour market transitions. Their significance is discussed later in the conclusion. 


\section{$4 \quad$ Results}

Table 1 shows the broad definitions of each case, the categories that distinguish them, and the ideal types of labour market transition to which they lead. The first row shows the titles we have given each study, each of which is defined in terms of broad occupational type (and which may apply to comparable courses elsewhere) with the actual subject areas where we collected data given in the row below. Following these descriptors, six defining categories are set out: The study locations; the status of the occupations students were being prepared for; valued areas of learning content; the form of socialisation they underwent; the dominant sources of the expertise students acquired; and the nature of the credentials they would gain. The final row summarises the processes of labour market transition for which we will suggest in the conclusion that they appeared to be destined.

Table 1: Overview of Cases

\begin{tabular}{|c|c|c|c|c|}
\hline \multirow{2}{*}{ 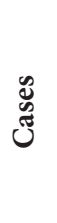 } & Categories & $\begin{array}{l}\text { Professional- } \\
\text { Technical }\end{array}$ & $\begin{array}{c}\text { Care and Personal } \\
\text { Services }\end{array}$ & Creative \& Design \\
\hline & Occupational areas & $\begin{array}{l}\text { Professional } \\
\text { construction }\end{array}$ & $\begin{array}{l}\text { Personal services (e.g. } \\
\text { hair, beauty); early } \\
\text { years education }\end{array}$ & $\begin{array}{l}\text { Software engineering } \\
\text { and creative media }\end{array}$ \\
\hline \multirow{6}{*}{ 莺 } & Study locations & $\begin{array}{l}\text { National specialist } \\
\text { (with managed } \\
\text { accommodation) }\end{array}$ & $\begin{array}{l}\text { Localised, high } \\
\text { level of work-based } \\
\text { learning }\end{array}$ & $\begin{array}{l}\text { Classroom-based, with } \\
\text { problematic study } \\
\text { locations }\end{array}$ \\
\hline & Occupational status & High & Low & Emerging \\
\hline & $\begin{array}{l}\text { Valued learning } \\
\text { content }\end{array}$ & $\begin{array}{l}\text { Professional: } \\
\text { specialist learning } \\
\text { related to work roles }\end{array}$ & $\begin{array}{l}\text { Routinised: arising } \\
\text { incidentally from } \\
\text { work processes }\end{array}$ & $\begin{array}{l}\text { Network: projects } \\
\text { commissioned by } \\
\text { professional clients }\end{array}$ \\
\hline & Socialisation & $\begin{array}{l}\text { Professional: } \\
\text { developing ability to } \\
\text { network with industry } \\
\text { professionals }\end{array}$ & $\begin{array}{l}\text { Routinised: } \\
\text { socialised into } \\
\text { acceptance of caring } \\
\text { responsibilities and } \\
\text { routine roles }\end{array}$ & $\begin{array}{l}\text { Networked: } \\
\text { developing abilities to } \\
\text { network with } \\
\text { industry/creative } \\
\text { actors/cosumers }\end{array}$ \\
\hline & Sources of expertise & Academic & Work-based & Networked \\
\hline & Credentialisation & Academic & Vocational & Technocratic \\
\hline 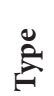 & $\begin{array}{l}\text { Labour market } \\
\text { transition }\end{array}$ & $\begin{array}{l}\text { Technical elite } \\
\text { formation }\end{array}$ & Welfare VET & $\begin{array}{l}\text { New economy } \\
\text { precarity }\end{array}$ \\
\hline
\end{tabular}




\subsection{Study Locations}

All of the case studies collected data mainly in college settings rather than the workplace; yet significant differences were evident in the locations and their significance for each case. Within the voluntarist framework in England, colleges have the responsibility to select or allocate placement opportunities and the learning and work opportunities they might offer. In the professional-technical case study, both work-based and college-based components were highly organised. Students employed by national companies stayed in residential accommodation that the provider organised, and which Ofsted (national quality agency for schools and colleges) inspected. There has been evidence in early "T Level" developments that placements in these areas can be highly beneficial but also difficult to secure (Newton et al., 2018) and these opportunities were highly valued.

By contrast securing a placement was seen as easy in the "care and personal services" case, especially for industries where students as "casual" staff can provide capacity at busy times. However, these could be of variable quality and learning opportunities were contingent on the activity of the business. For example, a hairdressing student explained that she was using a limited range of skills working on the pensioners' day on Wednesdays:

It was different to here [college workshop], where they are teaching you how to do it, they correct you if you go wrong. But with work experience, really you're just sweeping and cleaning and, you know, washing hair. (Emma, hairdressing student)

This did not provide opportunities to develop skills such as cutting and colouring hair, nor opportunities to develop professional networks which might have provided opportunities for paid employment on qualification: Emma was being used as a form of "cheap labour" (Sally, beauty teacher).

On the "creative and design" pathway, however, even these limited opportunities were less readily available. Student "projects" provided by employers provided opportunities to apply course concepts in practice, and to develop useful skills in research and networking expertise. However, in industries structured around networked micro-businesses, colleges found it difficult to arrange placements that met the requirements of national policy, which required location in an industry setting, whilst avoiding placing students alone with a single individual in a micro-business. An important distinction between the professional-technical and other cases, then, was the opportunities that the former provided to acquire, through placements, specialist knowledge and experience that would not be available in colleges. 


\subsection{Occupational Status}

Each type of work-based learning was discursively positioned to reinforce the status of occupations for which they were positioning the learner. In the professional-technical case, this affirmed the relatively high status that students were expected to achieve by sharp discursive differentiation from "craft" occupations. The field of professional construction where the data was collected prepares candidates for employment as surveyors, architectural technicians and site managers. Where colleges in the past have supported students or adults who had trained for craft occupations to access professional qualifications, this was emphatically ruled out. Teaching staff reported a shift from "many years ago [when] if you wanted to be a construction manager you had to be a joiner and a bricklayer" (Paul, construction lecturer). Craft occupations were described as a route for young people who if successful might end up running their own building company. By contrast, "young professionals" were destined for more attractive careers:

They're looking to get a degree and perhaps then go on to get a masters, which is becoming more and more of a requirement, and then to move into management and work on some of the world's very interesting projects. So there is the split now, and it isn't what the joiners used to do. (Paul, construction lecturer)

Yet by contrast, the other case studies produced little or no evidence that the students' experiences of work led to a higher evaluation of their occupation's social worth. Even in educational settings, students mainly reported carrying out routine tasks that led to a diminution of self-worth, with opportunities to read to or work with children directly highly prized by placement students. Students in creative and design areas remained unclear about their futures, reflecting the uncertainty of jobs in these sectors.

\subsection{Valued Learning Content}

Just as the locations, and their consequent opportunities to learn, varied significantly across the three case studies, different aspects of knowledge were valued. On the professional-technical case study, students engaged with an unusually high level of theorised knowledge. Correspondingly, apprenticeships in such areas have retained taught qualifications whilst many service-sector apprenticeships are now taught entirely in the workplace (Fuller \& Unwin, 2017; Esmond, 2019) and students reported the intensity of college-based study. Practical aptitude was clearly valued and respondents listed practical achievements alongside the high school grades as enabling them to join the course: Jack, a former lifeguard had taken on plant maintenance at his swimming pool, whilst Phil on the same course cited practical projects for family members. Yet the same students reported their college-based learning as valued 
in the workplace and, as we will see, this translated into a high valuation of classroom-based knowledge.

By contrast, "care and personal services staff" valued practical skills yet sometimes found it difficult to use these on placement. Placements in these areas were sometimes presented to students as opportunities to experience work rather than to learn. In these cases, learning at work depended on the arbitrary quality of work experiences and serendipitous opportunities arising from work experience. Yet it was unclear how they were directly orientated to labour markets as a result of this learning, with some hairdressing staff and students noting that placements appeared to have displaced earlier vacancy opportunities.

In this respect, the projects completed by students in digital and creative areas offered better opportunities to demonstrate practical skills than those completing placements, where socialisation into routines predominated. For creative and design students, the knowledge required for commissioned projects was accessed largely independently of organisational constraints and internet-based. Although staff articulated a need for practical applications, students provided no real indication of evaluating any kind of internet-based learning content any differently.

\subsection{Socialisation}

The accounts of students across all cases conveyed the significance of social dimensions. In the professional-technical case, this took on professional aspects: the course leader spoke of "presenting to main boards and corporate entities ... writing technical reports and having to adapt them to a non-technical audience" (Neil, course leader). This process of socialisation extended from dress codes to the accommodation described above: Upper secondary students lived with "approved landladies" expected to ensure students were home for 10pm; those on higher levels progressed to student accommodation. In this context, we see the (predominantly male-dominated) groups being socialised into what might be described as a "professional habitus" associated with greater access to valorised capitals.

By contrast, placements in the care and personal services case were those where socialisation into emotional labour is deemed essential (Colley, 2006). Compared to students in more "technical" disciplines, students preparing for more service-based fields encountered greater emphasis on socialisation than on technical skills during their lengthy work placements. Whilst interpersonal skills associated with customer service and communication are essential for those in directly customer-facing roles, this can contribute to a sharper differentiation in the FE sector in England where general education subjects are excluded from curricula. In contrast, in those programmes for lower attaining young people and in low status, female-dominated programmes such as childcare, we see students being socialised into specific forms of vocational habitus (Colley, 2006) associated with emotional labour, with 
"skills" such as self-presentation, time-keeping and obedience (Tomlinson, 2013, p. 69) and with low paid and precarious employment.

The significance of these socialisation processes is attested by government insistence that T Level students on creative and design courses will need to complete industry placements, in spite of the practical difficulties involved. They may be able to access the same networked knowledge inside and outside work organisations; but without placements, full-time students will not be subject to the expectations of a sector characterised less by industrial discipline than by short-term employment and insecurity.

\subsection{Sources of Expertise}

The professional-technical case study revealed an unexpected tension between industry and academic expertise. The course leader described his efforts to recruit and retain teachers with contemporary industry expertise but this appeared to play out in a less direct focus on practical problems at work than might be expected from the valorisation of technique. This preference for knowledge available in the college over cutting-edge industrial practice supported the observation that this case appeared to valorise abstract, institution-based knowledge. Staff were often studying for academic credentials: "We really promote the staff to complete masters and PhDs: A very academic team" (Neil, course leader). English vocational teachers often hold higher industry qualifications than academic credentials: Unlike many European countries, teachers in engineering are also particularly likely to hold sub-bachelor teaching qualifications (Frontier Economics, 2018). Yet precisely in a sphere where important learning opportunities were available at work, great emphasis was placed on academic expertise for tutors and for students.

Students not only accepted this approach but saw their tutors, rather than the expertise available in their companies, as the key personal resource of knowledge. The research team probed this preference in interviews: Researcher: "Do you get out and talk to experts in the field or visit sites where it [an advanced technique]'s being used, or a project where it's being used?" Phil:

Well I've been [i.e. worked] on a few myself, actually, where it's been sort of, been implemented; but we've actually got Susie, one of our lecturers who is a specialist in [the technique] and she does quite a few lectures and she's quite, quite well known so she is a quite useful ... person to speak to you about it and learn from. (Phil, professional construction student)

At higher levels, participants reported the use of written dissertations to assess higher-level students for project work, a method more closely associated in England with final-year bachelor study than practice-based projects but now permitted on "higher national" qualifica- 
tions. Jack explained the absence of discussion around industry practice as the consequence of course specifications:

At the moment we're sticking to ... the guidelines of the course, so it's quite rare that ... we have a problem, bring it in and say to our lecturers, 'Can we have a word about this?' . . It's understanding what the course wants of us and then learning from that. (Jack, "higher national" student)

The significance of this data is that, in the case where the quality of learning opportunities at work appears highest, the most valued sources of expertise appear to be located in the classroom.

By contrast, students in personal service roles experienced the expertise of professionals differently. Here work-based practitioners were placed in highly valued expert roles and could be seen by students as gatekeepers who determined what they could learn at work. Students were often visited by assessors, who lacked the authority of classroom-based teachers or industry-based experts: Their role is expanding with the growth of workplace learning in England (Esmond, 2019). Even in an area with significant traditions of workplace learning, childcare students found their learning experiences contingent on the extent to which they were trusted by the other practitioners to deal with parents and children. Anna described different settings she had experienced:

I think when they don't push you, they just see you as a student and nothing else then it makes it seem like you can't do as much. But, then, if you go to one and they trust you, then you get to learn more ... [but with certain practitioners] you just get to do jobs which aren't important.

(Anna, childcare student)

A critical question rarely discussed in England at this stage is how teachers engage with the practice of their students, especially where those students have had different experiences and opportunities. Whilst some teachers in this study described different teaching strategies for building on their placement learning (e.g. shared reflections or discussions in the classroom), others left students to make their own connections between "classroom learning" and "workplace learning".

\subsection{Credentialisation}

A final key distinction among the case studies was their orientation to progression and credentials. Although the Sainsbury reforms offered to replace the vocational system wholesale (see above), and the terminology of "T Levels" is presented as an equivalent to the "A levels" that provide university progression, the three patterns emerging from the data show quite distinct orientations. 
The professional-technical case placed considerably greater emphasis on progression. Here the course leader reported his main motivation in building an upper secondary course as providing recruitment to higher level courses. The vision of a distinctive route to higher levels of study completes the distinction between this and other routes. By contrast, progression to higher levels featured very little in the data from personal service and caring occupations, or in the creative and digital fields that made up the final case study. Although progression to higher levels of study is widely available in such areas as healthcare and early childhood education, work placements in these areas were never discussed as facilitating progression to degree-level studies: in these cases, work placements were seen more clearly as progression routes into employment where credentials play a less significant role in selection.

\subsection{Labour Market Transitions}

Having categorised these diverse learner experiences, we can begin to summarise how these early experiences of work in England position young people for labour market transitions. The case studies provided evidence that workplace learning entails more far-reaching processes than providing students with specialist industry skills. Even on the professional route, important propositional knowledge is acquired in classroom settings, and learning at work entails important socialisation activities, preparing students for lengthy pathways (usually via higher education) into higher levels of employment and its expectations. Other routes prepare learners for social practice, either by accustoming them to workplace routine or discovering cultural norms of networked interaction. These are not new social processes but the move towards workplace learning in England appears to be reinforcing them in a more hierarchical form.

We therefore complete our case study by conditionally denoting three types of labour market transition which the move towards workplace learning appears to be setting in motion. We characterise the first as "technical elite formation", noting a partial separation of the upper strata of VET evident in other jurisdictions. We designate the support of transition to marginal service employment as "welfare VET", socialising many learners into poorly rewarded care roles. The difficulties of digital students in securing the briefest of placements reflect the contingent nature of employment in that field, notwithstanding the rewards available to more successful individuals, leading to our final designation of "new economy precarity". We discuss the implications of this typology in our conclusions.

\subsection{Conclusions}

The typology emerging from our case studies is provisional and is not claimed to be a universal description of an emerging VET fissure in England. Nevertheless, this increasing 
divergence corresponds broadly to the pattern of service employment discussed by Wren (2013), with professional construction contributing to the UK's globally traded services. Participation in this workforce generates very different rewards from those in Wren's (2013) "welfare" (the professional services provided by the state) and "non-dynamic" sectors (p. 13). Membership of such groups (and their reproduction) calls for very different preparation, and entails quite distinctive labour market transitions. Such a widening gap in VET would reflect the increasing levels of inequality in the UK.

We do not claim that this greater social (and educational) hierarchy is inevitable. Whilst it would build on England's foundations of liberal market skill formation, this would require conscious choices by policymakers. Nevertheless, these outcomes for workplace learning are more likely in the English context precisely because all forms of professional and vocational learning focus directly on practice. (The wider curricula of most European VET, extending to languages and broader social questions, are largely excluded even from the college curricula of these subjects.) Thus, the shift towards greater emphasis on placements can enhance the reproductive role of educational practice that vocational educators widely seek to interrupt.

Further research and unfolding events can confirm, refine or refute the relevance of our cases, and our typology of labour market transitions. These approaches may be sustained, and even enhanced, if the UK draws further away from European social models and becomes more profoundly aligned to more extreme versions of liberal market economy, although this remains a matter of political choice. At a moment of redefinition for the UK's position in relation to Europe, its position as a liberal market economy, may prove, as political economists suggest, self-reinforcing. It may be that other educational and political traditions and institutions enable other countries to resist these tensions. However, such theorisation offers no guarantee that VET elsewhere in Europe will not suffer fragmentation of a similar type, if at a different pace and on a different scale.

The aftermath of the COVID-19 pandemic may also strengthen a shift away from the classroom and towards learning at work, particularly if this is seen to help straitened state finances. It has also raised questions about which occupations and what aspects of their work should be valued, and by implication what educational preparation they require and deserve. There may be less acceptance that, for example, the education of care workers should primarily serve their marginalisation. At a probable moment of profound change, these cases draw attention to the possibility of a rising curve of inequality in VET.

\section{References}

Acemoglu, D., \& Autor, D. (2011). Skills, tasks and technologies: Implications for employment and earnings. In O. Ashenfelter \& D. E. Card (Eds.), Handbook of labor economics (pp. 1043-1171). https://dx.doi.org/10.3386/w16082 
Ainley, P., \& Corney, M. (1990). Training for the future: The rise and fall of the manpower services commission. Cassell.

Ante, C. (2016). The europeanisation of vocational education and training. Springer International $\mathrm{Pu}-$ blishing. https://dx.doi.org/10.1007/978-3-319-41570-3

Atkins, L. (2009). Invisible students, impossible dreams: Experiencing vocational education 14-19. Trentham Books. http://hdl.handle.net/10545/623927

Atkins, L. (2017). The odyssey: School to work transitions, serendipity and position in the field. British Journal of Sociology of Education, 38(5), 641-655. https://dx.doi.org/10.1080/01425692.2015.1131 146

Atkins, L., \& Duckworth, V. (2019). Research methods for social justice and equitiy in education. Bloomsbury. https://doi.org/10.1080/02660830.2019.1643561

Avis, J., \& Atkins, L. (2017). Youth transitions, VET and the "making" of class: Changing theorisations for changing times? Research in Post-Compulsory Education, 22(2), 165-185. https://dx.doi.org/10 .1080/13596748.2017.1314678

Billett, S., Thomas, S., Sim, C., Johnson, G., Hay, S., \& Ryan, J. (2010). Constructing productive postschool transitions: An analysis of Australian schooling policies. Journal of Education and Work, 23(5), 471-489. http://dx.doi.org/10.1080/13639080.2010.526596

Boles, N. (2016). Foreword by the Minister of State for Skills. In Department for Education/Department for Business, Energy, Innovation and Skills, Post-16 Skills Plan, (pp. 5-6).

Bosch, G. (2017). Different national skill systems. In C. Warhurst, K. Mayhew, D. Finegold \& J. Buchanan (Eds.), The Oxford handbook of skills and training (pp. 424-433). Oxford University Press. https://dx.doi.org/10.1093/oxfordhb/9780199655366.013.20

British Educational Research Association. (2018). Ethical Guidelines for Educational Research (4th ed.).

Busemeyer, M. R., \& Trampusch, C. (2012). The comparative political economy of collective skill formation. In M. R. Busemeyer \& C. Trampusch (Eds.), The political economy of collective skill formation (pp. 3-40). Oxford University Press. https://dx.doi.org/10.1093/acprof:o so/9780199599431.003.0001

Cantor, L. M., \& Roberts, I. F. (1972). Further education in England and Wales (2nd ed.). Routledge and Kegan Paul.

Chankseliani, M., \& Relly, S. J. (2015). From the provider-led to an employer-led system: Implications of apprenticeship reform on the private training market. Journal of Vocational Education \& Training, 67(4), 515-528. https://dx.doi.org/10.1080/13636820.2015.1076499

Clarke, L., \& Winch, C. (2015). Have Anglo-Saxon concepts really influenced the development of European qualifications policy? Research in Comparative and International Education, 10(4), 593606. https://doi.org/10.1177\%2F1745499915613247

Colley, H. (2006). Learning to labour with feeling: Class, gender and emotion in childcare education and training. Contemporary Issues in Early Childhood, 7(1), 15-29. http://dx.doi.org/10.2304/ ciec.2006.7.1.15

Corbin, J. M., \& Strauss, A. (2015). Basics of qualitative research: Techniques and procedures for developing Grounded Theory (4th ed.). Sage.

Department for Education/Department for Business, Energy, Innovation and Skills. (2016). Post-16 skills plan. https://assets.publishing.service.gov.uk/government/uploads/system/uploads/attachment_data/file/536043/Post-16_Skills_Plan.pdf 
Employment and Social Developments in Europe. (2015). Review. Directorate-General for Employment, Social Affairs and Inclusion Office. https://op.europa.eu/en/publication-detail/-/ publication/9e6d6a27-c977-11e5-a4b5-01aa75ed71a1

Esmond, B. (2018). "They get a qualification at the end of it, I think": Incidental workplace learning and technical education in England. Journal of Vocational Education and Training, 70(2), 193-211. https://dx.doi.org/ 10.1080/13636820.2017.1393000

Esmond, B. (2019). Emerging apprenticeship practitioner roles in England: Conceptualising the subaltern educator. Vocations and Learning. https://dx.doi.org/10.1007/s12186-019-09233-0

European Centre for the Development of Vocational Training. (2018). The changing nature and role of vocational education and training in Europe. Volume 3: the responsiveness of European VET systems to external change (1995-2015). Cedefop research paper; No 67. Publications Office. http://data. europa.eu/doi/10.2801/621137

European Commission. (2016). A new skills agenda for Europe: Working together to strengthen human capital, employability and competitiveness. European Commission. https://eur-lex.europa.eu/legalcontent/EN/TXT/?uri=CELEX:52016DC0381

Eurostat. (2019). Youth unemployment rate by sex [dataset]. Eurostat. https://ec.europa.eu/eurostat/ databrowser/view/tesem140/default/table?lang=en

Felstead, A., Fuller, A., Jewson, N., \& Unwin, L. (2009). Improving working as learning. Routledge.

Frontier Economics. (2018). Further Education workforce data for England: Analysis of the 2016-2017 staff individualised record (SIR) data. Education and Training Foundation.

Fuller, A., \& Unwin, L. (2017). Apprenticeship quality and social mobility. In Sutton Trust (Ed.), Better Apprenticeships (pp. 9-36). Sutton Trust.

Gehin, J.-P. (2007). Vocational education in France: A turbulent and peripheral role. In L. Clarke \& C. Winch (Eds.). Vocational Education: International Approaches, Developments and Systems. Routledge.

Glaser, B. G. (1965). The constant comparative method of qualitative analysis. Social Problems, 12(4), 436-445. https://doi.org/10.2307/798843

Goos, M., \& Manning, A. (2007). Lousy and lovely jobs. The rising polarization of work in Britain. The Review of Economics and Statistics, 89(1), 118-133. https://EconPapers.repec.org/RePEc:tpr:restat :v:89:y:2007:i:1:p:118-133

Greinert, W.-D. (2005). Mass vocational education and training in Europe: Classical models of the 19th century and training in England, France and Germany during the first half of the 20th. Cedefop. https://www.cedefop.europa.eu/files/5157_en.pdf

Hardy M., \& Ménard, L. (2009). School/Workplace Partnerships: A case study of four vocational studies programmes. In R. Maclean, \& D. Wilson (Eds.), International handbook of education for the changing world of work. Springer.

Harper, D. (2002). Talking about pictures: A case for photo elicitation. Visual Studies, 17(1), 13-26. https://doi.org/10.1080/14725860220137345

Hodkinson, P., Sparkes, A., \& Hodkinson, H. (1996). Triumphs and tears: Young people, markets and the transition from school to work. David Fulton.

Hodgson, A., Spours, K., \& Smith, D. (2017). Future apprenticeships in England: The role of mediation in the new model. Journal of Education and Work, 30(6), 653-668. https://dx.doi.org/10.1080/136 39080.2017.1349299 
Holmes, C., \& Mayhew, K. (2012). The changing shape of the UK job market and its implications for the bottom half of earners. Resolution Foundation.

Iannelli, C., \& Raffe, D. (2007). Vocational upper-secondary education and the transition from school. European Sociological Review, 23(1), 49-63. http://dx.doi.org/10.1093/esr/jcl019

Illeris, K. (2011). Workplaces and learning. In M. Malloch, L. Cairns, K. Evans \& B. N. O’Connor (Eds.), The Sage handbook of workplace learning (pp. 32-45). Sage.

Independent Panel on Technical Education. (2016). Report of the independent panel on technical education. Department for Education. http://hdl.voced.edu.au/10707/407545

Keep, E., \& James, S. (2012). A Bermuda triangle of policy? "Bad jobs", skills policy and incentives to learn at the bottom end of the labour market. Journal of Education Policy, 27(2), 211-230. https:// doi.org/10.1080/02680939.2011.595510

Kis, V., \& Windisch, H. (2018). Making skills transparent: Recognising vocational skills acquired through workbased learning. OECD Education Working Papers, No. 180, OECD Publishing. https://doi. org/10.1787/5830c400-en

MacDonald, R., \& Marsh, J. (2005). Disconnected youth? Growing up in Britain's poor neighbourhoods. Palgrave.

Marginson, S. (2016). The worldwide trend to high participation higher education: Dynamics of social stratification in inclusive systems. Higher Education, 72(4), 413-434. http://dx.doi.org/10.1007/ s10734-016-0016-x

McIntosh, S. (2013). Hollowing out and the future of the labour market. BIS research paper, No. 134. Department for Business Innovation \& Skills. https://assets.publishing.service.gov.uk/government/uploads/system/uploads/attachment_data/file/250206/bis-13-1213-hollowing-out-and-future-of-the-labour-market.pdf

Méhaut, P., \& Winch, C. (2012) The European qualification framework: Skills, competences or knowledge? European Educational Research Journal, 11(3), 369-381. http://dx.doi.org/10.2304/ eerj.2012.11.3.369

Michelsen, S., \& Stenström, M. L. (2018). Vocational education in the nordic countries: The historical evolution. Routledge.

Ministry of Labour. (1964). Industrial training act. Legislation.gov.uk. http://www.legislation.gov.uk/ ukpga/1964/16/enacted

Mühlemann, S. (2016). The cost and benefits of work-based learning. OECD Education Working Papers, No. 143. OECD Publishing. https://doi.org/10.1787/5jlpl4s6g0zv-en

Newton, B., Williams, J., Francis, R., Gloster, R., Buzzeo, J., Myford, M., \& Esmond, B. (2018). Evaluation of the industry placements pilot. research report. Department for Education.

Nichols, B. (1991). Representing Reality. Indiana University Press.

Nilsson, A. (2010). Vocational education and training - an engine for economic growth and a vehicle for social inclusion? International Journal of Training and Development 14(4), 251-272. https://doi. org/10.1111/j.1468-2419.2010.00357.x

Office for National Statistics. (2018). All in employment by occupation (EMP08). https://www.ons.gov. uk/employmentandlabourmarket/peopleinwork/employmentandemployeetypes/datasets/allinemploymentbyoccupationemp08

Reed, M. I. (2018). Elites, professions, and the neoliberal state: Critical points of intersection and contention. Journal of Professions and Organization, 5(3), 297-312. https://dx.doi.org/10.1093/jpo/ joy010 
Richard, D. (2012). The richard review of apprenticeships. School for Startups.

Rose, G. (2016). Visual methodologies: An introduction to researching with visual materials (4th ed.). Sage.

Shildrick, T., MacDonald, R., Webster, C., \& Garthwaite, K. (2012). Poverty and insecurity: Life in lowpay, no-pay Britain. Policy Press.

Simmons, R. (2009). Entry to employment: Discourses of inclusion and employability in workbased learning for young people. Journal of Education and Work, 22(2), 137-151. https://dx.doi. org/10.1080/13639080902854060

Simmons, R., \& Thompson, R. (2011). NEET young people and training for work: Learning on the margins. Trentham Books.

Sorge, A., \& Streeck, W. (2018). Diversified quality production revisited: Its contribution to German socio-economic performance over time, Socio-Economic Review, 16(3), 587-612. https://dx.doi. org/10.1093/ser/mwy022

Streeck, W. (1991). On the institutional conditions of diversified quality production. In E. Matzner \& W. Streeck (Eds.), Beyond keynesianism: The socio-economics of production and full employment (pp. 21-61). Edward Elgar.

Tesch, R. (1990). Qualitative research. Analysis types and software. Falmer Press.

Thelen, K. (2004). How institutions evolve: The political economy of skills in Germany, England, the United States and Japan. Cambridge University Press.

Tomlinson, S. (2013). Ignorant yobs? Low attainers in a global knowledge economy. Routledge.

Thompson, R. (2019). Education, inequality and social class: Expansion and stratification in educational opportunity. Routledge.

UK Government. (2015). English apprenticeships: Our 2020 vision. BIS/15/604. Department for Business Innovation \& Skills.

Wellington, J. (2015). Educational research contemporary issues and practical approaches (2nd ed.). Bloomsbury.

Wesselink, R., de Jong, C., \& Biemans, H. J. A. (2010). Aspects of competence-based education as footholds to improve the connectivity between learning in school and in the workplace. Vocations and Learning 3(1), 19-38. https://dx.doi.org/10.1007/s12186-009-9027-4

Wolf, A. (2011). Review of vocational education. Department for Education.

Wren, A. (2013). The political economy of post-industrial societies. In A. Wren (Ed.), The political economy of the service transition (pp. 1-70). Oxford University Press.

Yin, R. K. (2018). Case study research and applications: Design and methods (6th ed.). Sage

\section{Biographical Notes}

Dr Bill Esmond is Associate Professor at the University of Derby. His research focuses on the boundaries between VET and employment relationships, and those between VET and higher education.

Professor Liz Atkins is Professor of VET and Social Justice at the University of Derby, UK. Her work on low-attaining young people includes the 2009 monograph, Invisible Students, Impossible Dreams (Trentham). 